\title{
Pedagang Etnis Cina di Pattallassang Kabupaten Takalar 1971-2017
}

\author{
Pertiwi Nanda Utami, Mustari Bosra, Asmunandar \\ Prodi Pendidikan Sejarah Fakultas Ilmu Sosial Universitas Negeri Makassar, Indonesia \\ qanita.pertiwi@gmail.com
}

\begin{abstract}
Abstrak
Penelitian ini bertujuan untuk mengetahui sejarah keberadaan pedagang Etnis Cina di Pattallassang Kabupaten Takalar (1971-2017), hubungan pedagang Etnis Cina dengan masyarakat setempat di tinjau dari segi ekonomi dan sosial, serta bagaimana pola perdagangan Etnis Cina. Penelitian ini merupakan penelitian sejarah yang menggunakan metode sejarah melalui tahapan kerja yakni heuristik atau pengumpulan data, kritik sumber, interpretasi, historiografi atau hasil penulisan. Kedatangan para pedagang Cina di Takalar khususnya di desa Pattallassang secara Historis belum ditemukan angka pasti, namun ditemukan bukti Arkeologi di daerah Pattallassang yaitu salah satu kuburan etnik Cina yang berkisar tahun 1953-an yang terdapat di batu nisan tersebut dan masih menggunakan ejaan lama seperti kata Kuburnja. Namun barulah pada tahun 1971, terdapat etnis Cina yang bekerja sebagai pedagang. Dalam proses perdagangan etnis Cina yang datang ke Kabupaten Takalar, mereka melakukan pembauran dengan masyarakat seperti perkawinan yang keturunannya kemudian disebut Cina peranakan. Istilah ini menunjuk pada masyarakat keturunan Cina yang kakek-neneknya telah menikah dengan masyarakat lokal yang juga dikenal dengan istilah Cina Baba dan Cina Nona. Sistem perdagangan yang dianut pedagang Etnis Cina berakar kuat pada sistem kongsi. Kongsi adalah suatu permufakatan antara dua orang atau lebih untuk melakukan usaha secara bersama dengan tujuan menikmati secara bersama manfaat atau keuntungan yang diperoleh dari usaha itu. Metode pengumpulan data dilakukan dengan cara penelitian lapangan terdiri dari wawancara ( Ryan Lie, Cici Nova, Ery Chou, Baba Henry, dan Baba Ling) dan mengumpulkan sumber arsip ( dokumen dari kantor desa dan BPS Kabupaten Takalar) serta literatur-literatur yang berhubungan.
\end{abstract}

\section{Kata Kunci : Pedagang, Etnis Cina, Pattallassang}

\begin{abstract}
The purpose of the research is to find out the history of the existence of Chinese Ethnic traders in Pattallassang, Takalar Regency (1971-2017), the relationship of Chinese Ethnic traders with local people in terms of economic and social aspects, and how the pattern of Chinese Ethnic trade. This research is a historical research that uses historical methods through work stages namely heuristics or data collection, source criticism, interpretation, historiography or writing results. The arrival of Chinese traders in Takalar, especially in the village of Pattallassang. Historically no exact figures have been found, but Archeological evidence is found in the Pattallassang area, which is one of the ethnic Chinese graves that revolves around the 1953 found in the tombstone and still uses the old spelling as said KUBURNJA . But it was only in 1971 that there were ethnic Chinese who worked as traders. In the process of ethnic Chinese trade that came to Takalar District, they did an assimilation with the community such as a marriage whose descendants were later called peranakan Chinese. This term refers to people of Chinese descent whose grandparents have been married to local people who are also known as Baba China and Miss China. The trading system adopted by Chinese ethnic traders is firmly rooted in the joint venture system. A partnership is an agreement between two or more people
\end{abstract}


to do joint business with the aim of enjoying together the benefits or benefits derived from the business. The data collection method was carried out by means of field research consisting of interviews (Ryan Lie, Cici Nova, Ery Chou, Baba Henry, and Baba Ling) and collecting archival sources (documents from the village office and BPS of Takalar Regency) and related literature.

\section{Keywords: Traders, Chinese Ethnic, Pattallassang}

\section{A. Pendahuluan}

Kedatangan imigran Cina dibeberapa wilayah Nusantara berlangsung sekitar abad ke-17 M, sebagian besar berasal dari daerah Tiongkok Selatan, terutama dari Fu Khien dan Kwantun, dimana setiap imigran tidak hanya membawa barang dagangan atau diri mereka saja tetapi juga berbagai aspek kebudayaan khas, termasuk sistem berdagang (ekonomi), bahasa, kepercayaan, teknologi, kesenian, dan sebagainya. (Sri Kartini, 2011).

Disetiap daerah pedagang Tiongkok membaur dengan kebudayaan setempat, sehingga terbentuknya suatu komunitas Tionghoa ditengah masyarakat lokal namun dengan budaya yang masih terjaga. Secara Kuantitatif, etnis Cina merupakan minoritas ditengah kemajemukan etnis Indonesia. Pada tahun 1961, Coppel memperkirakan ada sekitar 2,45 juta jiwa etnis Cina atau sekitar 2,5 persen dari total penduduk Indonesia (Abdullah \& Surjamihardjo, 1985: Riyanti, Puji. 2013).

Kehadiran orang Tionghoa di Sulawesi Selatan dilaporkan dengan jelas dalam masa kerajaan Gowa-Tallo. Orang Eropa pertama kali yang mengabarkan ini adalah George Cockayne, yang mengepalai loji Inggris di Makassar. Dalam sebuah surat bertanggal 16 Juli 1615 yang ditujukan kepada Sir John Smith, Gubernur dari East Indian Company (EIC), Cockayne melaporakan bahwa dia menjual beras pada seorang Tionghoa di kota tersebut yang memiliki penyulingan arak. ( Yerry Wirawan. 2013).

Dalam ingatan kolektif orang Tionghoa , seperti yang ditulis dalam sebuah artikel tahun 1932 oleh seorang bernama Seonhonghie dari Ampenan, pada pedagang pertama yang tiba di Makassar datang dari provinsi Fujian. Disaat itu pelabuhan Makassar belum ramai dan belum ada pedagang Eropa. Sipenulis menjelaskan bahwa hanya ada sebuah Jung (oewangkang) yang datang setiap tahunnya dengan membawa sekitar dua ratus penumpang dan sejumlah besar dari mereka memilih tidak kembali ke Tiongkok.

Hampir dapat dikatakan bahwa etnis Cina umumnya dikenal sebagai pedagang yang ulet dan banyak yang berhasil, karena pada masa lalu orang Cina secara politis sudah dibatasi ruang gerak dan jelajah pencahariannya, terutama setelah mereka dituding sebagai pendukung partai komunis di Indonesia akhir 1950-an sampai 1960-an. Mereka tidak diberi peluang menjadi pegawai negeri, tentara, ataupun polisi apalagi duduk dalam pemerintahan ataupun dalam parlemen. Kalaupun ada, tentu saja dengan melalui jalur khusus, memiliki prestasi atau kemampuan yang luar biasa, terlebih lagi setelah mereka dilarang untuk tinggal (bermukim) jauh kepelosok desa, sehingga bakat tani atau nelayan yang mungkin mereka miliki menjadi sirna tidak tersalurkan. Dengan kondisi yang demikian, mereka kemudian berusaha dan belajar dengan keras dalam hal perdagangan. Hal ini hampir dialami orang Cina dibeberapa wilayah di Indonesia.

Seiring dengan berkembangnya laju perdagangan dan kebijakan pemerintahan di Indonesia, pedagang Etnis Cina meluas hingga ke beberapa daerah di luar Makassar. Memasuki tahun 1960-an, yang menjadi awal terbukanya jalan etnik Tionghoa untuk memulai perdagangan 
yang mandiri di berbagai wilayah di luar Makassar. Salah satu daerah yang juga menjadi pilihan para pedagang etnis Cina untuk memulai jejak perdagangan mereka adalah Kabupaten Takalar yang pertama kali didiami pada tahun 1970-an oleh pedagang Cina bermarga Ming, kemudian disusul oleh beberapa pedagang etnis Cina yang lain hingga mampu membentuk suatu komunitas perdagangan di sana.

Keberadaan para pedagang Cina tersebut menjadi hal yang sangat disoroti seiring berkembangnya usaha mereka, namun hal menarik dari pola perdagangan komunitas Cina tersebut adalah tidak lunturnya budaya asli mereka sekalipun perdagangannya semakin modern. Hal inipun masih sangat jelas terlihat dibeberapa daerah yang mayoritas penduduknya adalah penduduk lokal setempat yang mempunyai budaya yang berbeda dengan minoritas pedagang Cina. Namun mereka dapat berbaur dengan mempertahankan ciri khas budayanya sehingga hal ini dianggap menarik untuk dikaji lebih lanjut.

\section{B. Metode Penelitian}

Penelitian ini menggunakan metode penelitian sejarah yang terdiri dari empat tahap, yaitu heuristik (mencari dan mengumpulkan sumber). Penulis melakukan wawancara terhadap beberapa pedagang etnis Cina dan masyarakat lokal, seperti Ryan Lie, Cici Nova, Ery Chou, Baba Henry, dan Baba Ling dan beberapa pedagang local di Pattallassang. Adapun bahan-bahan pustaka penulis diperoleh dari sejumlah perpustakaan, sepertii Perpustakaan Sejarah FIS-UNM, Perpustakaan UNM, Perpustakaan Wilayah Provinsi Sulawesi Selatan, Perpustakaan UNHAS, Perpustakaan dan Arsip daerah Kabupaten Takalar, Badan Arsip dan Perpustakaan Daerah Sulawesi Selatan serta Balai Pelestarian Sejarah dan Nilai Tradisional Makassar. Selanjutnya, penulis melakukan kritik baik kritik ekstern dan kritik intern, interpretasi (penafsiran sumber) dan historiografi (penulisan sejarah). Metode pengumpulan data dilakukan dengan cara melakukan penelitian lapangan (wawancara, pengamatan dan penelitian pustaka.

\section{Tinjauan Penelitian}

Kabupaten Takalar yang hari jadinya pada tanggal 10 Februari 1960, proses pembentukannya melalui tahapan perjuangan yang panjang. Sebelumnya, Takalar sebagai Onder afdeling yang tergabung dalam daerah Swatantra MAKASSAR bersama-sama dengan Onder afdeling Makassar, Gowa, Maros, Pangkajene Kepulauan dan Jeneponto.

Onder afdeling Takalar, membawahi beberapa district (Adat Gemen Chap) yaitu: District Polombangkeng, District Galesong, District Topejawa, District Takalar, District Laikang, District Sanrobone. Setiap District diperintah oleh seorang Kepala Pemerintahan yang bergelar Karaeng, kecuali District Topejawa diperintah oleh Kepala Pemerintahan yang bergelar Lo'mo.

Upaya memperjuangkan terbentuknya Kabupaten Takalar, dilakukan bersama antara Pemerintah, Politisi dan Tokohtokoh masyarakat Takalar. Melalui kesepakatan antara ketiga komponen ini, disepakati 2 (dua) pendekatan/cara yang ditempuh untuk mencapai cita-cita perjuangan terbentuknya Kabupaten Takalar, yaitu:

1. Melalui Lembaga Perwakilan Rakyat Daerah (DPRD) Swatantra Makassar. Perjuangan melalui Legislatif ini, dipercayakan sepenuhnya kepada 4 (empat) orang anggota DPRD utusan Takalar, masing-masing H. Dewa'

Dg. Tiro, Daradda Dg. Ngambe, Dg. Mattola dan Abd. Mannan Dg. Liwang.

2. Melalui pengiriman delegasi dari unsur pemerintah bersama tokoh-tokoh masyarakat. Mereka menghadap Gubernur Provinsi Sulawesi Selatan di Makassar menyampaikan aspirasi, agar harapan terbentuknya Kabupaten Takalar segera terwujud. Mereka yang 
menghadap Gubernur Sulawesi adalah Bapak H. Makkaraeng Dg. Manjarungi, Bostan Dg. Mamajja, H. Mappa Dg. Temba, H. Achmad Dahlan Dg. Sibali, Nurung Dg. Tombong, Sirajuddin Dg. Bundu dan beberapa lagi tokoh masyarakat lainnya.

Upaya ini dilakukan tidak hanya sekali jalan. Titik terang sebagai tanda-tanda keberhasilan dari perjuangan tersebut sudah mulai nampak, namun belum mencapai hasil yang maksimal yaitu dengan keluarnya Undang-Undang RI Nomor 2 Tahun 1957 (LN No. 2 Tahun 1957) maka terbentuklah Kabupaten Jeneponto-Takalar dengan Ibukotanya Jeneponto. Sebagai Bupati Kepala Daerah yang pertama adalah Bapak H. Mannyingarri Dg. Sarrang dan Bapak Abd. Mannan Dg. Liwang sebagai ketua DPRD.

Para politisi dan tokoh masyarakat tetap berjuang, berupaya dengan sekuat tenaga, agar Kabupaten Jeneponto-Takalar segera dijadikan menjadi 2 (dua) Kabupaten masing-masing berdiri sendiri yaitu: Kabupaten Jeneponto dan Kabupaten Takalar.

Perjuangan panjang masyarakat Kabupaten Takalar, berhasil mencapai puncaknya, setelah keluarnya UndangUndang RI Nomor 29 Tahun 1959 (LN Nomor 74. Tahun 1959), tentang Pembentukan Daerah-Daerah Tingkat II di Sulawesi Selatan dimana Kabupaten Takalar termasuk didalamnya.

Berdasarkan Undang-Undang Nomor 29 Tahun 1959 itu, maka sejak tanggal 10 Februari 1960, terbentuklah Kabupaten Takalar, dengan Bupati Kepala Daerah (Pertama) adalah Bapak H. Donggeng DG. NGASA seorang Pamongpraja Senior.

Kabupaten Takalar merupakan salah satu wilayah kabupaten di Provinsi Sulawesi Selatan yang terlatak pada bagian selatan. Letak astronomis Kabupaten Takalar berada pada posisi $53^{\circ}-538^{\circ}$ Lintang Selatan dan $11922^{\circ}-1139^{\circ}$ Bujur Timur, dengan luas wilayah kurang lebih 566,51 $\mathrm{Km}^{2}$. Secara administrasi Kabupaten
Takalar memiliki wilayah berbatasan dengan: Sebelah Utara berbatasan dengan Kabupaten Gowa, Sebelah Timur berbatasan dengan Kabupaten Gowa dan Kabupaten Jeneponto, Sebelah Selatan berbatasan dengan Selat Makassar, dan Sebelah Barat berbatasan dengan Laut Flores.

Wilayah administrasi Kabupaten Takalar hingga tahun 2006 terdiri atas 7 kecamatan, dan pada tahun 2007 mengalami pemekaran wilayah menjadi 9 kecamatan. Dua wilayah kecamatan hasil pemekaran adalah Kecamatan Sanrobone yang dimekarkan dari Kecamatan Mappakkasunggu, dan Kecamatan Galesong yang dimekarkan dari Kecamatan Galesong Utara dan Galesong Selatan. (Takalar, 2013)

Sumber data dari BPS Kabupaten Takalar, menunjukkan wilayah kecamatan terluasa dalah Kecamatan Polombangkeng Utara dengan luas kurang lebih 212,25 $\mathrm{Km}^{2}$, atau sekitar 37,47\% dari luas wilayah Kabupaten Takalar, sedangkan kecamatan yang memiliki luas terkecil adalah Kecamatan Galesong Utara dengan luas wilayah kurang lebih $15,11 \mathrm{Km}^{2}$ atau sekitar 2,67\% dari luas Kabupaten Takalar.

Kondisi iklim wilayah Kabupaten Takalar dan sekitarnya secara umum ditandai dengan jumlah hari hujan dan curah hujan yang relatif tinggi, dan sangat dipengaruhi oleh angin musim. Pada dasarnya angin musim di Kabupaten Takalar dipengaruhi oleh letak geografis wilayah yang merupakan pertemuan Selat Makassar dan Laut Flores, kondisi ini berdampak pada putaran angin yang dapat berubah setiap waktu, halte rutama terjadi pada Kecamatan Mangarabombang, sehingga pada beberapa kawasan diwilayah ini mengalami kekeringan terutama pada musim kemarau.

Berdasarkan hasil pengamatan stasiun hujan di Kabupaten Takalar, menunjukkan suhu udara minimum rata-rata $22,2^{\circ} \mathrm{C}$ hingga $20,4^{\circ} \mathrm{C}$ pada bulan Februari-Agustus dan suhu udara maksimum mencapai $30,5^{\circ} \mathrm{C}$ hingga $33,9^{\circ} \mathrm{C}$ pada bulan 
September-Januari. Tingkat curah hujan dan jumlah hari hujan dalam periode empat tahun terakhir mengalami perubahan intensitas curah hujan setiap tahunnya, dengan rerata terbesar terjadi pada tahun 2007 yang mencapai 107hh dengan curah hujan 555,42 mmHg. Dalam kurun waktu tersebut, jumlah hari hujan terendah terjadi pada tahun 2004 yaitu 88 Hari hujan, sedangkan curah hujan terendah terjadi pada tahun 2006 dengan rerata intensitas curah hujan menacapai $192 \mathrm{mmHg}$.

\section{Pembahasan}

\section{Pedagang Etnis Cina Di Desa Pattallassang}

Kedatangan etnis Cina di Nusantara termasuk kabupaten Takalar, didorong oleh beberapa faktor, antara lain karena etnik Cina sudah terkenal dalam berniaga dan merupakan etnis yang suka mencari tempat baru dalam perdagangan, dan adanya konflik dalam negerinya yang berkecamuk pada abad ke-17 M.

Kedatangan para pedagang Cina di Takalar khususnya di desa Pattallassang secara Historis belum ditemukan angka pasti. Etnis Cina datang ke Takalar sudah lama sehingga tidak mengetahui kapan waktu pastinya. Menurut para pedagang Cina, leluhur mereka sudah ada di Takalar sebelum kemerdekaan. Namun secara umum kedatangan Etnik Cina di Nusantara sekitar abad ke-17 rata-rata berasal dari Tiongkok Selatan dari Provinsi Fu Khein dan Kuang Tung. (Andi Pallawa dan Aziz Asfat. 2003.)

Namun ada pula yang menyebutkan bahwa para imigran Etnis Cina yang tersebar di Indonesia mulai dari abad ke-16 sampai pertengahan abad ke-19 asal suku bangsa mereka adalah Hokkien, mereka berasal dari Provinsi Fu Khien bagian selatan. (Koentjaraningrat. 1997)

Dalam masyarakat suku Makassar masih di temukan bekas-bekas komunitas etnis Cina yang bermukim di pelosok, misalnya di daerah Sanrobone, Galesong dan Pattallassang yang ada di kabupaten Takalar berupa pemakaman. Etnis Cina tersebut dikenal pula sebagai pedagangpedagang yang ulet sebagai memasok barang-barang kebutuhan masyarakat dan raja disana. Selain itu, merekapun banyak yang melakukan perkawinan dengan orang setempat atau dengan keluarga bangsawan. Jika keluarga yang mereka kawini adalah keluarga petani dengan tanah yang luas, maka orang Cina tersebut turut pula terlibat dalam kegiatan pertanian sebagai mata pencarian kedua (sampinan) akan tetapi mata pencaharian utamanya adalah berdagang. Adapun bukti Arkeologi yang ditemukan khusus di daerah Pattallassang yaitu salah satu kuburan etnik Cina yang berkisar tahun 1953-an yang terdapat di batu nisan tersebut dan masih menggunakan ejaan lama seperti kata Kuburnja. Namun barulah pada tahun 1971, terdapat etnis Cina yang bekerja sebagai pedagang di Pattallassang, karena sebelumnya mereka ada yang bekerja hanya sebagai tukang saja.

Masyarakat Cina di Pattallassang hidup seperti kebanyakan masyarakat lainnya. Banyak yang menjadi pengusaha, akan tetapi tidak sedikit pula yang karena pendidikannya mereka bisa menjadi guru disekolah atau menjadi dokter dan sebagainya. Dalam dunia usaha yang paling menonjol tingkat kehidupannya adalah Etnik Cina Totok maupun Cina peranakan. Mereka rata-rata memiliki usaha yang cukup besar seperti menjadi pengusaha dialer motor dan mobil, ekspor-impor, real estate, hotel, travel, perbankan dan lainnya.

Etnis Cina pertama yang datang dikabupaten Takalar adalah imigran dari Provinsi Fujian yakni keluarga bermarga Ming. Mereka berlayar pertama kali ke selat Makassar dengan tujuan berdagang porselen Cina, sutra, dan arak lalu menetap disana sehingga kedatangan orang Cina di Takalar kebanyakan berasal dari Makassar. Sekitar tahun 1970-an setelah kemerdekaan mereka merantau ke pelosok daerah dan menginjakkan kaki pertama kali di Kecamatan Polongbangkeng Selatan namun pada saat itu mereka belum dikategorikan sebagai seorang pedagang. 
Pada awal kedatangan Etnik Cina tidak serta merta memegang kendali Ekonomi. Mereka hanya sebagai pedaganag eceran sebagai tenaga buruh, penjual sayur, tukang tambal gigi, pemilik warung kopi dan sebagainya. Akan tetapi tidak dapat dipungkiri pula bahwa pada saat itu juga terdapat saudagar-saudagar kaya yang ikut berdagang di daerah Makassar dan sekitarnya.

Gelombang kedua yang datang ke Makassar sekitar tahun 1972 adalah keluarga bermarga Nio. Awal kedatangan mereka sekeluarga sama sekali tidak mempunyai niat untuk berdagang namun lebih karena ingin mencari pengalaman hidup di negeri orang. Beberapa pedagang etnis Cina berasal dari daerah Sumatera Selatan yang menetap di Makassar pada tahun 1969. Setelah menetap disana sampai generasi ke-tiga, kemudian mereka merantau dan memilih menetap di desa Pattallassang sekitar tahun 1998 hingga sekarang.

Dari data tersebut dapat disimpulkan bahwa dari kurun waktu awal tahun 1970an hingga mendekati tahun 2000,ada tiga gelombang etnis Cina yang menjadi pemula komunitas pedagang di tengah masyarakat lokal kabupaten Takalar yakni etnis Cina bermarga Ming, Nio, dan Chou. Mereka datang bukan hanya ingin mencari penghidupan yang lebih baik di Negara orang semata, namun mereka membaur dengan masyarakat lokal dengan budaya yang tetap mereka jaga.

Kabupaten dengan etnis Cina terbanyak terdapat pada Kabupaten Pattallassang yaitu 220 orang. Berdasarkan kutipan wawancara diatas di perkuat dengan informasi lisan bahwa kedatangan Etnik Cina di Takalar terkhusus di Desa Pattallassang kebanyakan berasal dari Makassar, oleh karena itu kajian tentang Etnik Cina di Makassar sebelum tahun 1971 di Makassar sangatlah membantu untuk mengetahui asal usul Etnik Cina di Takalar.

Sebagian besar Etnik Cina datang ke Takalar dengan mengandalkan keterampilan, keberanian, dan keuletan untuk berusaha. Pada awal kedatangannya mereka membuka usaha di bidang perdagangan ada yang bertoko, berjual-jual kain, ada membuka warung.

Minoritas Etnik Cina yang berada di daerah Pattallassang ini adalah bukan lagi Cina asli namun mereka sudah menjadi campuran atau keturunan dalam hal ini sudah menjadi Cina peranakan karena telah berasimilasi danmengadakan pembaruan di daerah ini dimana orang tuanya perpaduan antara warga Cina dengan peduduk lokal.

Seperti yang dikemukakan seorang warga keturunan Cina peranakan yang bertempat tinggal di desa Pattallassang yang selain menjadi Ibu Rumah Tangga juga Berdagang Kursi Plastik termasuk perabotan rumah di tempat ini, dia mengemukakan bahwa:

"Kami berada disini bukan lagi orang
Cina asli, namun kami sudah menjadi
warga cina keturunan karena orang
tua kami sudah menikah dengan
orang penduduk sini, kalau mau lihat
cina asli ada di makassar misalnya
yang pakaiannya baju cina, kalau kita
sudah pakai baju biasa atau baju
sehari-hari seperti sekarang ini sudah
tidak bisa lagi dikatakan orang cina
asli karena sudah campuran.
begitupun dari segi bahasa didaerah
ini sebagian dari kami selain Makssar
dan bahasa indonesia tidak ada
bahasa lain yang kami tau. (Cici Nova,
2017)

Generasi muda keturunan cina dewasa ini sudah banyak yang tidak tahu lagi berbahasa cina, pendidikan formal tidak banyak menolong mereka. hal tersebut juga dipengarui karena kurangnya sekolah yang khusus untuk orang cina. semua pelajaran disekolah umum yang mereka tempati semuanya menggunakan bahasa Indonesia. Warga negara di Indonesia umumnya sudah tidak lagi paham bahasa Cina apapun kecuali 
beberapa istilah saja. hal itu karena sejak tahun 1958 pemerintah melarang etnik cina (yang sudah menjadi warga negara RI masuk sekolah asing dan pada tahun 1966, semua sekolah cina atau yang berbahasa cina di Indonesia ditutup oleh pemerintah.

\section{Hubungan Pedagang Etnis Cina Dan Masyarakat Lokal Di Desa Pattallassang a. Hubungan Sosial}

Masyarakat di Takalar khususnya di desa Pattallassang lumayan terbuka dalam hal menerima etnis lain dalam hal ini baik dari etnis Cina maupun etnis lainnya seperti Bugis. Namun yang sering menjadi perbincangan itu adalah hubungan antara orang Kristen dan orang Islam dalam rumah peribadatan. Kita bisa lihat pada masa sekarang dimana tak ada satupun tempat peribadatan bagi umat Kristiani dalam hal ini gereja.

Kurun waktu antara awal tahun 1970-an sampai tahun 2000 yang dianggap sebagai perkembangan paling terasa dalam alur perdagangan etnis Cina bukanlah waktu yang singkat. Dalam prosesnya etnis Cina asli yang datang ke Kabupaten Takalar melakukan pembauran dengan masyarakat seperti perkawinan yang keturunannya kemudian disebut Cina peranakan. Istilah ini menunjuk pada masyarakat keturunan Cina yang kakek-neneknya telah menikah dengan masyarakat lokal yang juga dikenal dengan istilah Cina Baba dan Cina Nona.

Adapun ciri-ciri Etnis Cina peranakan secara umum ditunjukan sebagai berikut:

1) Mereka adalah anak kawin campuran dari imigram Cina dengan wanita Indonesia , dan mereka biasanya turun temurun menikah dengan penduduk lokal atau sesame peranakan Cina sendiri.

2) Mereka biasanya sudah tidak terlalu tahu berbahasa Cina, mereka lebih sering berbahasa dialek orang setempat.

3) Mereka dilahirkan di Indonesia, dan kebanyakan diantara mereka tidak pernah kembali ke tanah leluhurnya. (Iwan Sumantri. 2004).

Orang keturunan Cina asli senantiasa mempertahankan kemurnian darah keturunan Cinanya dengan membatasi diri dalam hubungan social dengan pribumi seperti dalam sistem pernikahan. Mereka melakukan perkawinan dengan sesama etnis Cina saja. Dalam kehidupan sehariharipun mereka masih memelihara dengan baik berbagai bentuk kehidupan yang beridentitas Cina. Misalnya dalam sistem kepercayaan, mereka masih setia menganut ajaran Konghucu, Tao, dan Budha, yang kadang-kadang disebut sebagai agama nenek moyang.

Sementara orang Cina Peranakan adalah orang Cina yang sudah terikat pernikahan dengan orang pribumi. Sehingga darah Cina yang mengalir dalam diri mereka tidak lagi asli.Dalam kehidupan sehari-hari orang Makassar dan orang Cina bergaul dengan harmonis dan saling berterima kasih antara satu dengan lainnya. Demikian halnya dengan pembentukan kebudayaan, masing-masing membuka diri untuk mendapat pengaruh dan saling mempengaruhi. Sehingga dalam pola kehidupan social dan kebudayaan makassar dapat ditemukan unsur-unsur kebudayaan Cina. Sebaliknya dalam kehidupan orang Cina pun di Makassar terutama orang Cina Peranakan dapat ditemukan unsur-unsur kebudayaan Makassar yamg sudah membaur.

Tidak dipungkiri bahwa beberapa daerah yang terdapat Etnis Cina dan Etnis Lokal hidup dalam satu wilayah dan saling menginginkan kehidupan yang sejahtera baik dalam bidang ekonomi, maupun dalam bidang social seperti kesempatan memperoleh pendidikan, pelayanan kesehatan dan urusan social lainnya.Secara historis ditemukan dalam bidang social ada beberapa hal yang menjadi perhatian utama yaitu; Masalah pendidikan dan keterampilan, masalah kesehatan dan masalah urusan kematian. Masalah pendidikan dan keterampilan yang dimaksud, seperti menjahit, menggunting pakaian dan belajar. (arsip Nasional RI Sulawesi Selatan, 1950).

Dalam hubungan budaya, para saudagar Cina Totok maupun Cina Peranakan 
memberi hari libur khusus bagi pegawai mereka yakni disetiap hari perayaan baik hari raya Imlek, Idul Fitri mapun Idul Adha. Berkaitan dengan budaya etnis Tionghoa sepertinya selalu dijaga sekalipun dalam hal perdagangan, hal tersebut terbukti dengan adanya kertas jimat dan altar pemujaan disudut toko mereka.

Etnis Cina yang berkeluarga dengan masyarakat lokal membentuk komunitas dagang sendiri yang terdapat disepanjang persimpangan Pattallassang kecamatan Polongbangkeng Selatan kabupaten Takalar. Toko-toko mereka saling berhadapan dengan toko pedagang lokal yang beberapa diantara mereka adalah keluarga dari pihak istri yang dipersunting orang Tionghoa.

\section{b. Hubungan Dagang}

Kabupaten takalar dapat dikatakan tidak seperti daerah lain dimana dapat dijumpai etnis cina yang bertebaran di segala penjuru, hanya sebagian besar saja dari mereka yang mampu membuka usaha dagang didaerah ini, terkadang tidak nampak dari luar dan tidak dapat pula di bedakan yang mana toko milik etnis cina maupun toko milik masyarakat setempat, jadi kesannya tidak ada pedagang etnis cina.

Namun hal menarik yang menjadi sorotan para pedagang Etnis Cina dalam hubungan dagang dengan masyarakat setempat adalah usahawan keturunan Cina dalam berdagang, mereka tidak mau kompromi, terutama menyangkut kualitas barang, untung, dan rugi. Prinsip usahawan Cina adalah "lebih baik mengambil untung sedikit, yang penting kualitas dan pelayanan yang baik". Makanya banyak masyarakat lokal yang sering datang berbelanja ke toko milik usahawan pendatang Cina tersebut.

Dalam hubungan perdagangan, para saudagar Cina mempekerjakan masyarakat lokal sebagai penjaga toko ataupun rekan bisnis yang saling kerjasama dalam modal maupun pemasaran dagangan mereka. Seperti pernyataan Baba Henry (2017), ia mengatakan bahwa, "Para pedagang Cina terutama Cina Totok yang biasanya punya toko yang sudah besar sekitar tahun 1980- an, biasanya menjadi mandor dagang bagi pedagang kecil setempat." Dalam hal ini istilah mandor dagang dikenal dengan hubungan patron dan klien. Para pedagang kecil yang menjadi klien biasanya juga berperan sebagai pelanggan tetap ditokotoko saudagar cina tersebut. Seperti pernyataan salah seorang pedagang local di Takalar yang mengatakan:

"Salah satu bentuk hubungan lainnya antara pedagang Cina dan masyarakat lokal yakni sudah terbangun kepercayaan diantara mereka seperti seorang pedagang Takalar yang dipercaya menjalankan cabang sebuah toko emas milik saudagar Cina bermarga Chou sekitar tahun 1999. (Wawancara dengan Dg.Nguntung. 06 Oktober 2017)

Dalam hal perdagangan, pedagang etnis Cina sangat disiplin terhadap etos kerja yang mereka miliki. Etos kerja orang Tionghoa yang berdasar padadisiplin, bakti keluarga, toleransi besar pada rutinitas, dan pragmatisme yang kuat (Ch'ng, 1995:52). Alur ekonomi wirausahanya segera muncul dalam bentuk:

1) Handal dan dapat dipercaya.

2) Kekuatan hubungan dan jaringan.

3) Sifat hemat

4) Kreativitas dan inovatif

5) Munculnya etos bisnis, etos kerja, dan etos wiraswasta dan wirausaha. (ch'ng, 1995 :55-63)

Jadi dengan demikian nilai-nilai dalam keluarga sudah menjadi faktor stabilisasi dan mengikat dalam siklus masyarakat, dan menjamin bahwa pekerjaan-pekerjaan yang paling diperlukan oleh masyarakat akan terus berlangsung. Bagi usahawan keturunan Cina berpendapat bahwa dengan mewariskan pekerjaan ayah kepada anak maka keahlian dapat diwariskan secara turun-temurun. Itulah sebabnya usahawan pendatang Cina secara turun-temurun mewarisi pekerjaan orang tuanya.

Dalam hubungan para pedagang Cina dengan masyarakat lokal bisa juga terlihat dari aktivitas perdagangan mereka. Di desa Pattallassang, para pedagang Etnis Cina tidak hanya berdakang toko, dan warung 
saja. Tetapi merekapun menggunakan layanan jasa yang para pekerjanya adalah masyarakat lokal Pattallassang

\section{Sistem dan Perkembangan Perdagangan Etnis Cina Di Desa Pattallassang Pada Tahun 1971-2017}

\section{a. Sistem Perdagangan}

Usahawan keturuan Cina dalam melakukan usaha ekonomi, juga banyak dikondisikan oleh nilai dan norma yang mereka anut. Dalam mencari penghidupan orang-orang Cina di Takalar lebih memilih untuk berdagang. Mereka mempunyai wawasan dan visi yang jauh ke depan. Usahawan keturunan Cina memandang pekerjaan sebagai tradisi keluarga. Pekerjaan sebagai pedagang merupakan warisan dari orang tuanya.

Sistem perdagangan yang dianut pedagang Etnis Cina berakar kuat pada sistem kongsi. Kongsi adalah suatu permufakatan antara dua orang atau lebih untuk melakukan usaha secara bersama dengan tujuan menikmati secara bersama manfaat atau keuntungan yang diperoleh dari usaha itu.

Titik berat tujuan kongsi tersebut bagi masyarakat Tionghoa adalah menumbuh kembangkan kehidupan perekonomiannya. Kongsi dilakukan antara keluarga, masyarakat sekitar, atau dengan para pejabat demi menjaga keamanan dan kelancara usahanya. Misalnya, masyarakat Tionghoa menjalin hubungan dengan penguasa. Hubungan ini terjadi karena kesamaan kepentingan, dimana pedagang Cina memerlukan perlindungan dari hukum dan pesaing dagang mereka, sementara penguasa membutuhkan uang untuk menjaga prestise social mereka. Yang dijaga oleh pedagang Cina adalah agar mereka bisa memanfaatkannya untuk mengembangkan aktivitas ekonomi mereka.

Menurut salah seorang pedagang lokal di Pattallassang yaitu Dg Tinggi (Wawancara Oktober: 2018), mengatakan bahwa: "Beberapa model sistem perdagangan yang di gunakan oleh pedagang etnis Cina di Pattallassang seperti: a) Pedagang perantara, baik pedagang besar ataupun pedagang kecil, dihampir seluruh jenis perdagangan.

b) Pedagang kelontong (tekstil) mulai dari pemilik toko-toko, dan jumlah yang terbesar ialah sebagai penjaja keliling.

c) Pedagang grosir (partai besar), terutama dalam bidang-bidang palawija, gula, batik, beras, rokok, rotan dan mebel.

d) Pedagang legal ataupun ilegal dalam jenis-jenis candu (opium), dan rumah gadai

e) Pengutang keliling (=Tionghoa mindering).

Sebagai pedagang perantara orang Tionghoa memperlancar dan mengintensifkan korelasi perdagangan antara para saudagar dengan Masyarakat lokal Tionghoa mengambil dan mendapat keuntungan dari transaksi perantara ini. Orang Tionghoa juga menjadi kolaborator "orang di atas" Belanda untuk atas nama langsung atau tidak langsung, menekan "si kecil" Masyarakat lokal. Hal ini sangat bercitra negatif di tengah masyarakat. Memang harus diakui, bahwa antara para pedagang Masyarakat lokal juga menjabat pedagang perantara, namun kalau Masyarakat lokal berfungsi ilegal maka Masyarakat lokal tergolong oleh istilah "bangsa atau sesama bangsa" di antara masyarakat luas, Masyarakat lokal terbenam karena kesamaan ciri fisik yang ada. Sebaliknya dengan pedagang perantara Tionghoa karena ciri fisiknya yang berbeda dengan ciri orang Masyarakat lokal pada umumnya, maka Orang Tionghoa menampak beda identitas fisiknya di tengah masyarakat Masyarakat lokal.

Sebagai pedagang kelontong tekstil, terkadang Orang Tionghoa menjajakan dagangan sampai di desa-desa atau di kampung-kampung dengan memakai pemikul barang orang "Masyarakat lokal" dan berjalan di depan kurang lebih 2 - 3 meter sambil membawa alat yang berbunyi "kelenting kelontong", sehingga dari jauh pedagang ini dikenal, dan para 
calon pembeli telah siap menunggunya. Segi positif dari perdagangan Orang Tionghoa sebagai pedagang perantara yang terjun ke bawah dan dengan demikian melayani rakyat banyak. Segi negatifnya ialah sering pedagang kelontong "menipu” rakyat banyak, baik dari kualitas kain maupun harga kain. Barulah apabila pembelinya sesama orang Tionghoa, mereka lebih berhati-hati karena untuk kelompok ini tidak mudah ditipunya.

Sebagai pedagang grosir di bidang yang tersebut di muka, maka segi positifnya mirip sebagai perdagangan perantara kecil atau menengah. Sisi positifnya pedagang ini dipercaya sebagai pedagang yang berhasil dan berstatus sedikit di atas pedagang perantara menengah lainnya. Kelompok pedagang ini memiliki hubungan yang harmonis dengan pejabat pemerintah Belanda atau grosir-grosir Belanda juga. Sudah barang tentu mereka jarang berkomunikasi langsung dengan lapisan masyarakat menengah atau bawah. Sisi negatifnya, oleh masyarakat menengah dan bawah, mereka dianggap tangan kanan Belanda atau bahkan telah dianggap sama dengan kelompok elite (atas) Belanda. Pedagang grosir ini juga memiliki hak-hak yang luas di kalangan sipil atau pejabat teras atas dan dipercaya untuk menjadi pemuka masyarakat.

Sebagai pedagang legal - ilegal untuk jenis-jenis bahan "maksiat" seperti opium, rumah gadai atau mindering, maka jelasjelas mereka dikutuk masyarakat banyak. Bahkan istilah Cino kejam dan Cino = Sucine Ora Ono ini berasal dari prasangka jabatan-jabatan ini. Sedikitpun jabatan ini tidak bernilai positif, namun mereka menjadi cepat kaya raya dengan jabatan ini. Meskipun "cepat kaya raya", mereka dianggap penghisap rakyat, "benalu" murni yang sangat dibenci oleh rakyat banyak. Demikian suatu tugas ketekunan, ketelitian dan semangat kerja di bidang yang negatif, akan memiliki makna di hadapan masyarakat yang negatif pula.

Berkaitan dengan modal sosial usahawan keturunan Cina dibalik nilai dan norma yang mereka anut dapa menggambarkan bahwa dalam sistem keluarga usahawan Cina, etos kerja telah ditanamkan kepada anak-anak mereka sejak kecil. Bagi usahawan Cina, kerja dihubungkan dengan sekumpulan nilai kompleks yang mencakup pengorbanan diri, hemat, dan rasa percaya yang dipandang sebagai dasar terkumpulnya kekayaan. Etos kerja para usahawan Cina berorientasi kelompok. Setiap individu berpartisipasi dalam meningkatkan kesejahteraan keluarga, yang menjadi basis utama bagi kesejahteraan masyarakat. Usahawan pendatang keturunan Cina bekerja keras untuk mendapatkan imbalan materi. Kemakmuran dan kenyamanan dalam usia lanjut merupakan tujuan mereka dalam berusaha. Jadi mereka memandang kerja sebagai orientasi nilai instrumental.

\section{b. Pola dan Perkembangan Perdagangan}

Sejak masa penjajahan Kolonial Belanda, Etnik Cina di Indonesia merupakan golongan yang mendominasi hidup perdagangan. Hal tersebut terjadi karena pada masa tersebut diterapkan politik adu domba yang membagi tiga golongan masayarakat saat itu, yakni golongan pertama adalah orang-oramg Eropa sebagai pedaganag besar, golongan kedua ditempati oleh pedagang etnis Cina yang berlaku sebagai pedagang perantara antara orang Eropa dan masyarakat lokal. Golongan ketiga yaitu masyarakat petani, nelayan, pedagang eceran, dan buruh (Yerry Wirawan, 2013.)

Sejak awal tahun 1970-an di Kecamatan Pattallassang sudah ada Etnis Cina yang mulai melakukan aktivitas di bidang pedagangan baik yang berwarung, bertoko, dan berjualan emas dan sebagainya. Seperti pernyataan salah seorang pedagang Cina di Pattallassang yang mengatakan bahwa:

"Salah satu keturunan Tionghoa pertama yang ada di kabupaten Takalar 
adalah seorang pedagang wanita bernama Nona Mei, yang juga pendiri tokoh pertama di kabupaten Takalar pada tahun 1973 yang sekarang di kenal dengan 'Toko Mei'.Awalnya ia sekeluarga menetap di Makassar sebagai pedagang porselen, hasil karya tembikar danada pula yang bekerja sebagai tukang tambal gigi. Pada tahun 1971 Ia pertama kali menginjakkan kaki di kabupaten Takalar sekaligus menjadi Etnis Cina yang pertama ada di kabupaten Takalar.” (Wawancara dengan Baba Ling, Oktober: 2018)

Pada awal kedatangan Etnik Tionghoa tidak serta merta mendominasi ekonomi. Mereka hanya sebagai pedagang eceran juga sebagai tenaga buruh,penjual sayur dan sebagainya. Akan tetapi tidak dapat di pungkiri pula bahwa pada saat itu juga terdapat saudagar-saudagar kaya yang ikut berdagang di tengah masyarakat lokal. Pada umumnya para saudagar Cina tersebut menjadi pedagang barang-barang pokok yang memiliki harga tinggi ditengah masyarakat.

Di Kabupaten Takalar terkhusus di desa Pattallassang terdapat empat saranan perdagangan yang dilakoni oleh masyarakat di desa tersebut. Diantara keempat sarana tesebut, yang paling banyak digunakan adalah sarana perdagangan warung dan toko, kemudian disusul oleh saranan perdagangan pasar. Dari tabel diatas, dapat digambarkan bahwa khusus di desa Pattallassang terdapat 1 pasar induk, 96 toko, dan 68 warung. Dengan total sarana keseluruhan; 2 pasar, 323 toko, dan 358 warung. Diantara ketiga sarana ini, pedagang etnis Cina adalah minoritas masyarakat yang mengambil peran penting dalam perdagangan dengan sarana toko.

Pola perdagangan masyarakat Etnis Cina di tengah masyarakat lokal yang ada di kabupaten Takalar dapat dilihat sesuai dengan perkembangan tahun- ke tahun dimana etis Cina mulai banyak menetap di Kabupaten Takalar terkhusus di Desa Pattallassang. Beberapa pola perdagangan Etis cina termasuk dapat di gambarkan berdasarkan penuturan mereka dan pedagan local

Bentuk usaha dagang pertama di perkiraan tahun 1970-an oleh pedagang bermarga Ming, yakni berupa perdagangan tembikar. Yang kemudian berkembang menjadi tokoh kue, dan alat pecah belah 1973. Pedagang ini beriteraksi dengan masyarakat lokal menyesuaikan perdagangannya dengan kebutuhan dan minat masyarakat

Memasuki tahun 1975-an Etnis cina yang awalnya dilarang mencari penghidupan di pelosok wilayah kota Makassar karena kepres 14/1979 dan kepres 14a/1980 tentang pembatasan yang membatasi perdagangan orang cina mulai berimigrasi ke wilayah lain untuk mengembangkan dagangannya termasuk di Takalar. Kemudian pada awal 1980-an sudah di kenal dua marga besar pedagang Etnis Cina yang menjadi saudagar kaya di tengah masyarakat lokal saat itu yakni mrga Ming dan Nio.

Pada dekade tahun 1975-1985 dalam proses perdagangan etnis Cina masih menggunakan sistem barter dengan masyarakat setempat. Pada masa itu barang dagangan yang paling banyak diminati dan umumnya menjadi pilihan para pedagang Cina adalah perdagangan bahan sandang dan papan. Mereka tidak cukup tertarik dalam perdagangan di bidang pangan sehingga bahan pangan sering menjadi alat barter antara para pedagang Cina dan masyarakat lokal setempat.

Pada tahun 1990-2000 bukan hanya perdagangan barang-barang kebutuhan sandang dan pangan yang berkembang namun toko-toko pengobatan herbalpun berkembang dengan pesat.Pada tahun 2009 barang dagangan sudah mulai berkembang lebih beragam seperti lebih berjamurnya toko-toko kelontong, alat eletronik, dan perlengkapan rumah tangga.Dalam proses perdagangannya para pedagang etnis Cina tidak lupa dalam berinteraksi dengan masyarakat lokal. Namun hal yang menarik adalah budaya dan kepercayaan yang mereka anut juga turut mewarnai 
perdagangannya seperti adanya jimat dan altar pemujaan disetiap sudut toko yang mereka miliki.

Dalam sistem perdagangan masyarakat etnis Cina terbagi menjadi dua bagian yaitu kelompok pedagang Cina Totok dan Cina Peranakan. Pedagang Cina totok adalah pedagang masyarakat keturunan Cina asli yang perdagangannya lebih sedikit tertutup dan lebih banyak berinteraksi dengan sesama etnisnya saja. Umumnya kelompok ini berdagang barang yang biasanya dipakai bangsawan lokal masyarakat setempat seperti porselen, kain sutra, barang kelontongan, dan lainnya dalam jumlah besar dan berada ditengah kota/kabupaten tepatnya dipasar sentral Takalar. Sekalipun bersifat lebih tertutup tapi kelompok dagang ini juga menjalin hubungan dengan masyarakat lokal sebagai patron dan klien.

Masyarakat Cina Peranakan adalah pedagang dari keturunan estnis Cina yang sudah menikah dengan masyarakat pribumi. Sifat perdagangan mereka lebih terbuka dan berbaur dengan masyarakat pribumi. Umumnya pedagang Cina peranakan hanya berdagang barang kebutuhan sehari-hari dan lebih seperti pedagang barang campuran. Kelompok pedagang ini lebih sering berinteraksi dengan masyarakat lokal bahkan tidak jarang mereka bekerja sama dalam hal modal dan ketenagakerjaan.

\section{E. Kesimpulan}

Dari hasil penelitian yang telah dilakukan dapat ditarik beberapa kesimpulan sebagai berikut: kedatangan Etnis Cina di Kabupaten Takalar secara historis belum diketahui secara pasti, namun berdasarkan data wawancara dari pedagang Etnis Cina di Takalar, pedagang Etnis Cina pertama kali datang ke Kabupaten Takalar pada tahun 1970-an, dan bermukim di daerah Pattallassang.

Dalam hubungan sosial, Orang keturunan Cina asli senantiasa mempertahankan kemurnian darah keturunan Cinanya dengan membatasi diri dalam hubungan sosial dengan pribumi seperti dalam sistem pernikahan. Mereka melakukan perkawinan dengan sesama etnis Cina saja. Dalam kehidupan sehariharipun mereka masih memelihara dengan baik berbagai bentuk kehidupan yang beridentitas Cina. Misalnya dalam sistem kepercayaan, mereka masih setia menganut ajaran Konghucu, Tao, dan Budha, yang kadang-kadang disebut sebagai agama nenek moyang.

Dalam sistem dan pola perdagangan, dapat dilihat dari bentuk usaha dagang pertama yang diperkiraan tahun 1971 oleh pedagang bermarga Ming, yakni berupa perdagangan tembikar. Yang kemudian berkembang menjadi tokoh kue,dan alat pecah belah 1971. Pedagang ini berinteraksi dengan masyarakat lokal menyesuaikan perdagangannya dengan kebutuhan dan minat masyarakat.

\section{DAFTAR PUSTAKA}

Abdullah, T., \& Surjamihardjo, A. (1985). Arah, Gejala dan Perspektif Studi Sejarah Indonesia, dalam Ilmu Sejarah dan Historiografi, Arah dan Perspektif. Gramedia, Jakarta.

Alfian, 1998, Warga Tionghoa Mencari Keadilan, Bandung, Zaman.

Bahrum, 2008, Berubah Metamorphosis Warga Tionghoa Makassar Dalam 10 Tahun Reformasi, Makassar, Yayasan Baruga Nusantara.

Badan Pusat Statistik, 2009, Takalar Dalam Angka. Takalar, BPS Kab. Takalar.

Badan Pusat Statistik, 2013, Takalar Dalam Angka, Takalar, BPS Kab. Takalar

Hamzah, 1998, Warga Tionghoa Mencari Keadilan, Bandung, Zaman Wacana Mulia.

Kartini, 2011, Etnik Tionghoa Di Jeneponto 1956-2010, Skripsi UNM.

Koentjaraningrat, 1997, Manusia dan Kebudayaan di Indonesia, Jakarta, Djambatan.

Liem Tjoe, 2007, Rahasia Sukses Bisnis Etnik Tionghoa di Indonesia. Yogyakarta, Medpress. 
Muhammad, 2017, Modal Sosial Usahawan

Pendatang Di Kabupaten Takalar

Sulawesi Selatan, Sosiohumaniora, Vol. 19. Hal. 72.

Madjid, M. Saleh Dan Abd. Rahman

Hamid. 2008. Pengantar Ilmu

Sejarah. Makassar: Rayhan Intermedia

Madjid, 2008, Pengantar Ilmu Sejarah. Makassar, Raihan Intermedia.

Notosusant 1971, Norma-Norma Dasar Penulisan Sejarah, Jakarta, DEPHANKAM

Pallawa dan Aziz Asfat, 2003, Pembauran di Makassar, Makassar, Global Publishing.

Riyanti, 2013, Relasi Social Pedagang Etnis Cina Dan Etnis Jawa Dipasar Tradisional, Jurnal Sejarah, Vol, 1. No, 05.

Sumantri, 2004, Kepingan Mozaik Sejarah Budaya Sulawesi Selatan, Makassar Inninawa.

Wirawan, 2013, Sejarah Masyarakat Tionghoa Makassar Dari Abad Ke17 Hingga Ke-20, Jakarta, PT Gramedia 